spermathecal sac ( $B$ in the figure).

It was impossible to estimate the number of sperm cells for comparison between the control and group 1, but it is unlikely that sperm had been removed in the course of the short copulations because the inseminatory canal is very narrow, about the diameter of a sperm cell $^{4}$, and relatively long.

We doubt that there was a transfer of some substance that could selectively incapacitate the sperm of other males ${ }^{5}$ or cause its removal by the female ${ }^{6}$ during the first phase of copulation. Such substance, if deposited by the first four males in group 2, should have remained active and caused considerable decrease in female fecundity. But this was not the case (see table).

We conclude that during copulation in $C$. berlesei (and, presumably, in other acarid mites) males first transfer some substance which can push the previously deposited sperm away from the basal part of the spermatheca and the efferent

\section{Terpenes and forest decline}

SIR - Becker et al. imply ${ }^{1}$ that reactions of terpenes with ozone could have a more important role in the formation of hydrogen peroxide than the disproportionation reaction of peroxy radicals, thereby contributing to forest decline. The importance of the oxidation of terpenes to the atmospheric $\mathrm{H}_{2} \mathrm{O}_{2}$ budget can be estimated by using the authors' reported molar yields and terpene fluxes from coniferous forests. Lamb et al. ${ }^{2}$ reported $\alpha$-pinene fluxes of $1.15 \times 10^{-5}$ $\mathrm{mol} \mathrm{m} \mathrm{m}^{-2} \mathrm{~h}^{-1}$ for a Loblolly pine forest $(T$ $=30^{\circ} \mathrm{C}$ ). If one assumes a mixing height of $1 \mathrm{~km}$ and that $\beta$-pinene, $\Delta^{3}$-carene and $d$-liminone fluxes are similar, the resulting $\mathrm{H}_{2} \mathrm{O}_{2}$ production rate would be less than 6 p.p.t.v. (parts per $10^{12}$ by volume) $h^{-1}$. The disproportionation of peroxy radical $\mathrm{HO}_{2} \cdot+\mathrm{HO}_{2} \cdot \rightarrow \mathrm{H}_{2} \mathrm{O}_{2}$ would produce $25-700$ p.p.t.v. $\mathrm{H}_{2} \mathrm{O}_{2} \mathrm{~h}^{-1}$ $\left(k_{\mathrm{r}}=5.5 \times 10^{12} \mathrm{~cm}^{3}\right.$ per molecule $\mathrm{s}^{-1} ; T$ $=25^{\circ} \mathrm{C}$; relative humidity of $\left.50 \%\right)^{3}$ at $\mathrm{HO}_{2}$ levels of $10-15$ p.p.t.v. (which are thought to be typical midday levels $)^{4}$. Hence these calculations indicate that $\mathrm{H}_{2} \mathrm{O}_{2}$ production from the oxidation of terpenes may not be as important a source of atmospheric $\mathrm{H}_{2} \mathrm{O}_{2}$ as Becker et al. suggest.

The concentrations of reactants used by Becker et al. $\left[\mathrm{O}_{3}\right]_{0}=2-60$ p.p.m.v., [alkene] $]_{0}=5-35$ p.p.m.v.) are not relevant to the atmosphere. Concentrations of $\mathrm{O}_{3}$ in rural areas are generally of the order of 30-70 p.p.b.v. ${ }^{5}$; concentrations of terpenes, both in absolute terms and relative to $\mathrm{O}_{3}$ levels, in the ambient atmosphere are also much lower. Measurements indicate that total terpene ducts leading to the ovaries, and only then sperm is transferred. The chance that sperm repositioned and dispersed in the spermatheca will reach the efferent ducts again must be very low. It seems possible that this sperm is decomposed and finally resorbed by microvilli rich walls of the spermatheca ${ }^{4}$.

\section{Department of Zoopsychology and} Animal Ethology,

Institute of Environmental Biology, WOJCIECH WITALIŃSKI

Institute of Zoology,

Jagiellonian University,

Karasia 6,

30-060 Krakow, Poland

1. Parker, G. A. Biol. Rev. 45, 525-567 (1970).

2. Birkhead, T. R., Hunter, F. M. Trends Ecol. Evol. 5, $48-52(1990)$

3. Radwan, J. Behav. Ecol. Sociobiol. (in the press)

4. Witalinski, W.. Szlendak, E. \& Boczek, J. Expl. Appl. Acarol. 10, 1-31 (1990).

5. Silberglied, R. E., Shephred, J. G. \& Dickinson, J. L. Am. Nat. 123, 255-265 (1984).

Gilbert, D. G., Richmond, R. C. \& Sheehan, K. B. Evolution 35, 21-37 (1981).

concentrations in forest air during the summer are of the order of $0.1-10$ p.p.b.v. ${ }^{3,6}$. Highest concentrations are generally found at night since convection and vertical transport are lower; total terpene concentrations at midday are seldom larger than 1 p.p.b.v. Fluxes of terpenes from forests are dependent on various factors, including the plant species, time of year and leaf temperature ${ }^{7}$.

Becker et al. also noted that $\mathrm{H}_{2} \mathrm{O}_{2}$ production increased with addition of water to the reaction chamber. They attributed this to the acid/base catalysed reaction of the Criegee radical with water to form $\mathrm{H}_{2} \mathrm{O}_{2}$. However, with their experimental design and the blank tests reported, one cannot exclude reactions of water and $\mathrm{O}_{3}$ on glass surfaces to account for a portion of the increases in $\mathrm{H}_{2} \mathrm{O}_{2}$ concentrations, even though "rapid" appearance of $\mathrm{H}_{2} \mathrm{O}_{2}$ was observed. Such reactions are known to cause serious errors in $\mathrm{H}_{2} \mathrm{O}_{2}$ measurements ${ }^{8,9}$.

\section{Department of Meteorology,}

HOWARD B. ROSS Claes De Serves

Stockholm University,

S-106 91 Stockholm, Sweden

BECKER ET AL. REPLY - Ross et al. imply that the reactions of terpenes with ozone do not play an important role in the formation of hydroperoxides in the atmosphere and consequently in forest decline. Their estimation of the atmospheric hydrogen-peroxide budget using total terpene concentrations of about 1 p.p.b.v. is incorrect. The total terpene concentrations at midday are seldom higher than 1 p.p.b.v. because of the high oxidation rates. The estimation cannot be simply deduced from our re- ported values from the $\mathrm{H}_{2} \mathrm{O}_{2}$-yield table; these values were measured under high concentrations of $\mathrm{O}_{3}$ and terpenes, which result in high losses for the Criegee biradical by reactions with other species (such as $\mathrm{HCHO}$ and higher aldehydes). The estimation of the $\mathrm{H}_{2} \mathrm{O}_{2}$ formation rate, resulting from the reaction of the biradicals with water vapour, is only possible by a full kinetic simulation of forest-air chemistry. These simulation calcuations must include the emission rates of the terpenes ${ }^{10,11}$, the rate constants for the reactions $\mathrm{R}_{2} \mathrm{COO}$ $+\mathrm{H}_{2} \mathrm{O} \rightarrow \mathrm{H}_{2} \mathrm{O}_{2}$ and the yield for $\mathrm{H}_{2} \mathrm{O}_{2}$ formation for the different terpenes.

Ross et al. mention that the high concentrations used in our experiments were not relevant to the atmosphere. The relevance to atmospheric chemistry is given not by the concentrations used but by the occurrence of the reaction $\mathrm{R}_{2} \mathrm{COO}+\mathrm{H}_{2} \mathrm{O} \rightarrow \mathrm{H}_{2} \mathrm{O}_{2}$ in atmospheric photo-oxidant systems. The reactions were carefully analysed by evaluating "concentration-independent" kinetic parameters in the case of $\mathrm{C}_{2} \mathrm{H}_{4}$ and tetramethylethene and $\mathrm{O}_{3}$. The clearly established new reaction of water with biradicals seems to be an important $\mathrm{H}_{2} \mathrm{O}_{2}$ source in forest air and can possibly contribute to forest decline.

Heterogeneous formation of $\mathrm{H}_{2} \mathrm{O}_{2}$ on glass surfaces was ruled out by extensive blank tests. Details of these tests and their consequences for the kinetics of the reaction of the Criegee biradical with water were not reported in our paper ${ }^{1}$. Blank tests with even higher ozone concentrations (up to 400 p.p.m.v.) in the presence of water vapour (1-10 torr) have shown no $\mathrm{H}_{2} \mathrm{O}_{2}$ formation. References 8 and 9 are irrelevant to our work. These describe experiments in which $\mathrm{O}_{3}$ was bubbled through water. $\mathrm{H}_{2} \mathrm{O}_{2}$ formation in such systems can lead to interference in wet-chemical methods for $\mathrm{H}_{2} \mathrm{O}_{2}$ measurement, but certainly plays no role in our experiments. The high $\mathrm{H}_{2} \mathrm{O}_{2}$-yields recently observed with the wet-fluorescence method in the reactions of biogenic hydrocarbons with ozone in the presence of water vapour ${ }^{12}$ are possibly due to such interference. An

1. Becker, K. H.. Brockmann, E. J. \& Bechara, J. Nature 346, 257-258 (1990)

2. Lamb, B., Geunther, A., Gay, D. \& Westberg, H. Atmos. Environ. 21, 1433-1445 (1987).

3. Kircher, C. C. \& Sander, S. P. J. phys. Chem. 88, 2082-2091 (1984).

4. Trainer, M. et al. J. geophys. Res. 92, 11879-11894 (1987)

5. Logan, J. A. J. geophys. Res. 90, 10463-10482 (1985).

6. Lamb, B., Guenther, A., Gay, D. \& Westberg, H. Atmos. Environ. 8, 1693-1705 (1987)

7. Altshuller, A. P. Atmos. Environ. 17, 2131-2165 (1983)

8. Zika, R. G. \& Saltzman, E. Geolphys. Res. Lett 9, 231-234 (1982)

9. Helkes, B. G. Atmos. Environ. 20, 1433-1445 (1984). 10. Lamb, B., Westberg, H. \& Allwine, G. J. J. geophys, Res. 90, 2380-2390 (1985)

11. Zimmermann, P. R., Greenberg, J. P. \& Westberg, C. E. J. geophys. Res. 93, 1407-1416 (1988).

12. Simonaitis, R., Olszyna, K. J. \& Meagher, J. F. Geophys. Res. Lett. 18, 9-12 (1991). 